\title{
PENGARUH MODEL PEMBELAJARAN VALUE CLARIFICATION TECHNIQUE BERMEDIAKAN VIDEO TERHADAP HASIL BELAJAR PKN
}

\author{
Pt. Ratih Siswinarti \\ Jurusan Pendidikan Guru Sekolah Dasar, FIP, Universitas Pendidikan Ganesha \\ Singaraja, Indonesia \\ e-mail: siswinarti.ratih@gmail.com
}

\begin{abstract}
Abstrak
Permasalahan rendahnya hasil hasil belajar PKn siswa kelas V SD di Gugus III Kecamatan Seririt menjadi masalah utama dilakukannya penelitian ini. Rendahnya hasil belajar PKn terjadi karena pembelajaran masih berpusat pada guru dan siswa cenderung pasif. Oleh karena itu penelitian ini dilakukan dengan tujuan untuk mengetahui perbedaan hasil belajar dalam mata pelajaran PKn antara kelompok siswa yang dibelajarkan dengan model pembelajaran VCT berbantuan media video dan kelompok siswa yang dibelajarkan dengan pembelajaran konvesional pada siswa kelas V Semester II di SD Gugus III Kecamatan Seririt tahun pelajaran 2017/2018. Jenis penelitian ini adalah eksperimen semu, dengan desain penelitian Non Equivalen Post Test Only Control Group Design. Populasi penelitian ini adalah kelas V SD di Gugus III Kecamatan Seririt tahun pelajaran 2017/2018 yang berjumlah 143 orang. Sampel penelitian ini adalah kelas VA di SD Negeri 3 Seririt yang berjumlah 25 orang dan kelas V SD Negeri 1 Pengastulan yang berjumlah 21 orang. Metode pengumpulan data yang digunakan dalam penelitian ini adalah metode tes. Data yang dikumpulkan dianalisis menggunakan analisis statistik deskriptif dan statistik inferensial. Berdasarkan hasil perhitungan (uji-t) diperoleh thit $=6,092>t t a b=2,000$. Hal ini berarti terdapat perbedaan yang signifikan hasil belajar PKn antara kelompok siswa yang dibelajarkan dengan menggunakan model pembelajaran VCT berbantuan media video dan kelompok siswa yang dibelajarkan dengan pembelajaran konvesional. Sehingga dapat disimpulkan bahwa model pembelajaran VCT berbantuan media video berpengaruh terhadap hasil belajar PKn siswa.
\end{abstract}

Kata kunci: hasil belajar, VCT, video.

\begin{abstract}
The low civic education learning achievement of the fifth-grade elementary school students in Cluster III Seririt district became the main reason of conducting this research. The low achievement was caused by both teacher-centered learning style as well as the passive students. Therefore, the purpose of this research was to find out difference of students civics education learning achievement between those learning using VCT learning model mediated with video and those learning conventionally. This quasi experimental research used Non-Equivalent Post-test Only Control Group Design as the design of the study. It involved the fifth graders of elementary schools in cluster III Seririt district in academic year 2017/2018 (143 students). The sample of this study were class VA of SDN 3 Seririt (25 Students) and class V of SD N1 Pengastulan (21 Students). The data of this research were collected using test. The collected using test. The collected data were analyzed both descriptively and inferentially. The result shows that there is a significant difference on civics education learning achievement between students learning using VCT learning model mediated with video influences students civics education learning achievement.
\end{abstract}

Keywords: Result of study, VCT Learning Model, video 


\section{Pendahuluan}

Sekolah dasar merupakan tempat terjadinya proses interaksi antara siswa dengan siswa, siswa dengan guru maupun antarwarga sekolah. Interaksi yang lebih khusus lagi terjadi melalui pembelajaran di kelas. Pembelajaran adalah proses interaksi antara pendidik dan peserta didik yang bertujuan membantu peserta didik agar dapat belajar dengan baik (Susanto, 2013). Pembelajaran yang baik adalah pembelajaran yang aktif dan efektif. Aktif yang dimaksud adalah dalam proses pembelajaran guru harus menciptakan suasana sedemikian rupa sehingga peserta didik aktif bertanya, mempertanyakan, dan mengemukakan gagasan. Sedangkan yang dimaksud efektif adalah proses pembelajaran yang berlangsung dapat mencapai tujuan yang diharapkan (Syaifuddin, 2007). Pembelajaran yang seperti itu seharusnya terjadi pada semua mata pelajaran pada jenjang sekolah dasar termasuk mata pelajaran Pendidikan Kewarganegaraan (PKn).

Pendidikan kewarganegaraan adalah mata pelajaran yang memfokuskan pada pembentukan warga negara yang memahami dan mampu melaksanakan hak-hak dan kewajiban untuk menjadi warganegara Indonesia yang cerdas, terampil, berkarakter yang diamanatkan oleh pancasila dan UUD 1945.

Susanto (2013) menyatakan, pendidikan kewarganegaraan adalah usaha sadar dan terencana dalam proses pembelajaran agar peserta didik secara aktif mengembangkan potensi dirinya untuk memiliki kecerdasan, keterampilan, serta kesadaran tentang hak dan kewajiban sebagai warga negara, penghargaan terhadap hak asasi manusia, kemajemukan bangsa, pelestarian lingkungan hidup, kesetaraan gender, demokrasi, tanggung jawab sosial, ketaatan pada hukum, serta ikut berperan dalam peraturan global sesuai amanat pancasila dan UUD 1945.

Berdasarkan pengertian PKn oleh Susanto pembelajaran PKn di sekolah dasar diharapkan mampu memberikan pengetahuan tentang nilai-nilai kehidupan bagi siswa sehingga siswa memiliki pemahaman nilai dan pendidikan moral untuk meningkatkan kualitas diri dan kehidupannya dalam bermasyarakat, berbangsa dan bernegara. Nilai-nilai kehidupan yang dimaksud diantaranya siswa berani mengajukan pendapat ketika pembelajaran, mampu menjelaskan pendapatnya secara logis, mau menghargai pendapat orang lain, mampu berpikir secara kritis, rasional, dan kreatif dalam menanggapi persoalan hidup maupun isu kewaarganegaraan di negaranya, serta mampu memanfaatkan teknologi informasi dan komunikasi dengan baik. Oleh karena itu, sudah menjadi suatu keharusan apabila PKn di sekolah dasar diajarkan dengan penuh kebermaknaan dan diarahkan untuk penanaman nilainilai dan moral ke dalam diri siswa sehingga pemahaman terhadap nilai-nilai kehidupan tidak hanya sebatas materi saja, namun juga mampu untuk menerapkan dan mengamalkan nilai-nilai yang didapat dari pembelajaran PKn dalam kehidupan sehari-hari. Belajar bermakna dalam pembelajaran PKn artinya siswa mampu mengkaitkan informasi baru pada konsep-konsep relevan yang terdapat dalam struktur kognitif seseorang (Suwatra, dkk., 2015).

Dalam pembelajaran PKn guru dituntut untuk mampu menguasai konsep nilai-nilai yang terkandung dalam pendidikan kewarganegaraan dan menerapkan model yang dapat membuat suasana belajar menjadi kondusif, interaktif serta membuat siswa berperan aktif dalam mencari pengetahuannya sendiri.

Namun kenyataanya Pembelajaran PKn masih hanya sekedar memberikan ilmu pengetahuan untuk dihafalkan tanpa ada pemahaman dan pemaknaan terhadap nilai yang dipelajari sehingga belum terjadi peningkatan kualitas diri sebagai manusia dalam diri siswa itu sendiri. Penekanan makna dan pemahaman terhadap nilai dalam proses pembelajaran masih jarang dilakukan oleh pihak pengajar (Yuliasri, 2013).

Pembelajaran yang senada juga dapat dilihat di SD Gugus III Kecamatan Seririt. Hal ini diketahui dari hasil wawancara, observasi dan pencatatan dokumen terhadap 5 orang guru kelas V di Gugus III Kecamatan Seririt yang dilaksanakan pada tanggal 16 November hingga 21 November 2017. Hasil wawancara yang dilakukan terhadap 5 orang guru menyatakan kendala yang dihadapi dalam melaksanakan pembelajaran PKn adalah 1) Siswa cenderung pasif di dalam mengikuti pembelajaran, 2) Siswa malu bertanya dan mengungkapkan pendapat 
saat pembelajaran berlangsung mengenai masalah-masalah yang dihadapi terkait materi yang diberikan guru sehingga berimbas pada rendahnya kualitas pembelajaran.

Hasil wawancara diperkuat dengan hasil observasi, didapatkan hasil observasi sebagai berikut. 1) Dalam mengikuti pembelajaran hanya beberapa orang siswa yang mau menyampaikan pendapatnya saat diberikan pertanyaan oleh guru sehingga proses pembelajaran cenderung pasif, 2) Siswa malas untuk menanyakan hal-hal yang belum dipahami selama mengikuti pembelajaran, 3) Dalam proses pembelajaran guru tidak menggunakan media pada saat pembelajaran sehingga mengakibatkan pembelajaran kurang menarik yang berakibat siswa pasif dan bosan sehingga siswa tidak memahami materi PKn yang diberikan dan berdampak pada hasil belajar yang rendah, 4) Dalam proses pembelajaran guru jarang memberikan kesempatan pada siswa untuk mencari nilai yang dianggapnya benar dan menerapkan nilai tersebut dalam kehidupannya sehingga pemaknaan terhadap nilai itu kurang.

Selain kegiatan wawancara dan observasi, dilakukan pencatatan dokumen. Pencatatan dokumen diperoleh dari hasil rata-rata nilai hasil belajar ulangan tengah semester (UTS) pada semester I (ganjil) dari guru mata pelajaran PKn kelas V di seluruh SD di Gugus III Kecamatan Seririt Kabupaten Buleleng.

Rata - rata nilai UTS PKn siswa kelas V untuk setiap SD berkisar antara 65, 23 sampai 69,76 jika dikonversikan terhadap Penilaian Acuan Pedoman (PAP) pada skala 5 maka diakategorikan pada ketegori rendah. Sedangkan dilihat dari persentase ketuntasan sebanyak $57,34 \%$ siswa tidak tuntas. Hal ini menandakan hasil UTS PKn siswa kelas V di SD Gugus III Kecamatan Seririt masih cenderung rendah. Rendahnya hasil belajar ini harus diatasi, salah satu cara mengatasi masalah tersebut maka perlu diadakan perbaikan pola pembelajaran untuk meningkatkan hasil belajar siswa kelas $\mathrm{V}$ pada mata pelajaran PKn, dengan menerapkan model pembelajaran yang inovatif dan mampu melibatkan siswa secara aktif dalam pembelajaran sehingga apa yang dipelajari siswa tidak hanya sebatas hafalan namun ada pemaknaan terhadap nilai yang telah dipelajari sehingga berdampak pada hasil belajar yang dicapai oleh siswa. Salah satu model pembelajaran inovatif yang bisa meningkatkan hasil belajar PKn siswa adalah model pembelajaran Value Clarification Technique (VCT). Penerapan model pembelajaran Value Clarification Technique (VCT) sebagai usaha meningkatkan hasil belajar siswa dengan memberikan pembelajaran yang membuat siswa dapat memilih nilai secara bebas nilai yang diyakininya, pemaknaan terhadap nilai pembelajaran sehingga tidak hanya sebatas teori saja, serta siswa dapat berpartisipasi secara aktif dalam mengikuti pembelajaran.

Model pembelajaran VCT merupakan model inovatif yang menekankan nilai sosial, budaya, personal, dan masyarakat. Hall (dalam Adisusilo, 2014) menyatakan bahwa, VCT merupakan model pembelajaran nilai yang mampu mengantar peserta didik agar mempunyai keterampilan atau kemampuan menentukan nilai-nilai hidup yang tepat sesuai dengan tujuan hidupnya dan menginternalisasikannya sehingga nilai-nilai menjadi pedoman dalam bertingkah laku. Kemudian Hernivora (2014) menyatakan, VCT adalah suatu model pembelajaran yang melatih siswa untuk menilai, menerima, serta mengambil keputusan terhadap suatu persoalan dalam hubungannya dengan kehidupan sehari-hari di masyarakat. Pelaksanaan model pembelajaran ini akan lebih bermakna bila dipadukan dengan penggunaan media video. Media video merupakan jenis media audio/visual yang menyajikan pesan-pesan pembelajaran baik yang berisi konsep, prinsip, prosedur, teori aplikasi pengetahuan untuk membantu pemahaman terhadap suatu materi pembelajaran dalam bentuk gambar dan suara (Widiantari, 2013). Kelebihan dengan menggunakan media video dapat menarik dan memusatkan perhatian siswa serta memberikan gambaran nyata pada siswa tentang apa yang dipelajari selama proses pembelajaran.

Berdasarkan hal tersebut, dilakukan penelitian yang berjudul "Pengaruh Model pembelajaran Value Clarification Technique (VCT) berbantuan media video terhadap hasil belajar PKn siswa kelas V SD Gugus III Kecamatan Seririt Tahun Ajaran 2017/2018".

Tujuan penelitian ini adalah untuk mengetahui terdapat perbedaan yang signifikan hasil belajar PKn antara kelompok siswa yang dibelajarkan dengan model pembelajaran VCT 
berbantuan media video dan kelompok siswa yang dibelajarkan dengan pembelajaran konvensional pada siswa kelas V semester II SD di Gugus III Kecamatan Seririt Tahun Pelajaran 2017/2018.

\section{Metode}

Penelitian ini dilaksanakan di kelas VA SD Negeri 3 Seririt dan di kelas V SD Negeri 1 Pengastulan di Gugus III Kecamatan Seririt pada rentang waktu semester genap tahun pelajaran 2017/2018 yang dilaksanakan pada tanggal 3 April 2018 hingga 27 April 2018. Jenis penelitian ini adalah penelitian ini adalah eksperimen semu (quasi experiment). Penelitian ini menggunakan desain penelitian eksperimen yang digunakan dalam penelitian ini adalah non equivalent post-test only control group design. Terdapat dua kelompok dalam penelitian ini yang dipilih secara acak. Kelompok pertama diberi perlakuan (X) menggunkan model pembelajaran VCT berbantuan media video dan kelompok yang lain tidak diberi perlakuan (-). Kelompok yang diberikan perlakuan disebut kelompok eksperimen dan kelompok yang tidak diberi perlakuan disebut kelompok kontrol.

Pelaksanaan penelitian ini terdiri dari tiga tahap yakni tahap persiapan, tahap pelaksanaan, dan tahap pelaporan. Tahap persiapan terdiri dari merancang perangkat pembelajaran dan instrumen yang digunakan untuk penelitian, mengonsultasikan perangkat pembelajaran dan instrumen dengan pembimbing dan pakar, menguji instrumen yang digunakan untuk penelitian, melakukan analisis uji instrumen, merevisi instrumen penelitian yang telah dilakukan. Pada tahap pelaksanaan pertemuan diadakan sebanyak 7 kali pertemuan. 6 kali pertemuan untuk memberikan treatment dan 1 kali pertemuan untuk pemberian posttest. Langkah-langkah yang dilakukan pada tahap ini adalah memberikan perlakuan model pembelajaran VCT berbantuan media video pada kelas eksperimen dan pembelajaran konvensional pada kelas kontrol, kemudian mengadakan posttest pada kelas eksperimen dan kelas kontrol. Pada tahap pelaporan yang dilakukan adalah melakukan analisis data dilanjutkan dengan pengujian hipotesis sesuai data yang diperoleh dan menyusun laporan penelitian sesuai dengan analisis data yang didapatkan.

Populasi pada penelitian ini adalah seluruh kelas V Gugus III Kecamatan Seririt Tahun pelajaran 2017/2018 yang berjumlah 143 orang. Sampel yang digunakan telah diuji kesetaraannya menggunakan analisis varians satu jalur (Anava $A$ ) dengan hasil fhitung $=1,08$ lebih kecil dari ftabel=2,17. Sampel penelitian ini adalah siswa kelas VA di SD Negeri 3 Seririt yang berjumlah 25 orang sebagai kelompok eksperimen dan siswa kelas $V$ di SD Negeri 1 Pengastulan yang berjumlah 21 orang sebagai kelompok kontrol yang dipilih dengan teknik random sampling. Dalam penelitian ini terdapat dua variabel yakni variabel bebas dan variabel terikat. Model pembelajaran VCT berbantuan media video sebagai variabel bebas dan hasil belajar PKn sebagai variabel terikat.

Metode pengumpulan data dalam penelitian ini adalah metode tes. Sesuai dengan metode, maka instrumen yang digunakan dalam penelitian ini adalah tes objektif tipe pilihan ganda. Setiap item akan diberikan skor 1 untuk siswa yang menjawab benar dan skor 0 untuk siswa yang menjawab salah. Setelah instrumen tersusun, agar instrumen itu memenuhi syarat instrumen yang baik, maka dilakukanuji validitas, uji reliabilitas, uji tingkat kesukaran, dan uji daya beda tes. Uji validitas isi dilakukan dengan cara konsultasi kepada dua pakar (judges) terkait dengan soal hasil belajar PKn dengan hasil perhitungan 1,00 kategori sangat baik. Berdasarkan hasil ujidengan jumlah 39 tes didapatkan 2 tes tidak valid dan 37 butir tes valid, uji reliabilitas tes dengan hasil 0,9079 dengan kriteria sangat tinggi, uji daya beda tes dengan hasil 0,34 dengan kriteria cukup baik dan uji tingkat kesukaran tes dengan hasil 0,68 dengan kriteria sedang.

Untuk mendeskripsikan data yang diperoleh menggunakan analisis statistik deskriptif dan statistik inferensial melalui uji-t. Analisis statistik deskriptif meliputi: mean, median, modus, varians, dan standar deviasi. Sebelum dilakukan pengujian untuk mendapatkan kesimpulan, terlebih dahulu dilakukan uji coba normalitas menggunakan uji Chi-Kuadrat ( $\mathrm{x}$ ) pada taraf 
signifikansi $5 \%$ dan derajat kebebasan $\mathrm{db}=(\mathrm{k}-1)$. Dilanjutkan dengan dilakukannya uji homogenitas varians kelompok menggunakan uji $\mathrm{F}$ pada taraf signifikan $5 \%$ dengan derajat kebebasan untuk pembilang $n 1-1$ dan derajat kebebasan untuk penyebut $n 2-1$. Setelah data diketahui normal dan variannya homogen maka selanjutnya dilakukan uji hipotesis menggunakan uji-t sampel independent (tidak berkolerasi). Dalam penelitian ini rumus t-test yang digunakan untuk menguji hipotesis adalah polled varians.

\section{Hasil dan Pembahasan}

Data hasil penelitian ini adalah skor hasil belajar PKn siswa sebagai akibat dari penerapan model pembelajaran VCT berbantuan media video pada kelompok eksperimen dan pembelajaran konvensional pada kelompok kontrol. Data hasil belajar PKn kelompok eksperimen dan kelompok kontrol diperoleh dari hasil post-test. Pada kelompok eksperimen yang berjumlah 25 orang siswa didapatkan skor tertinggi adalah 30 dan skor terendah adalah 14. Dari skor yang diperoleh dapat dideskripsikan, yaitu mean $(M)=24,36$, median $(M d)=25,2$ modus $(\mathrm{Mo})=27$, varians $\left(\mathrm{s}^{2}\right)=20,91$, dan standar deviasi $(\mathrm{s})=4,57$. Data hasil tes belajar kelompok eksperimen disajikan ke dalam bentuk polygon seperti pada gambar 1 .

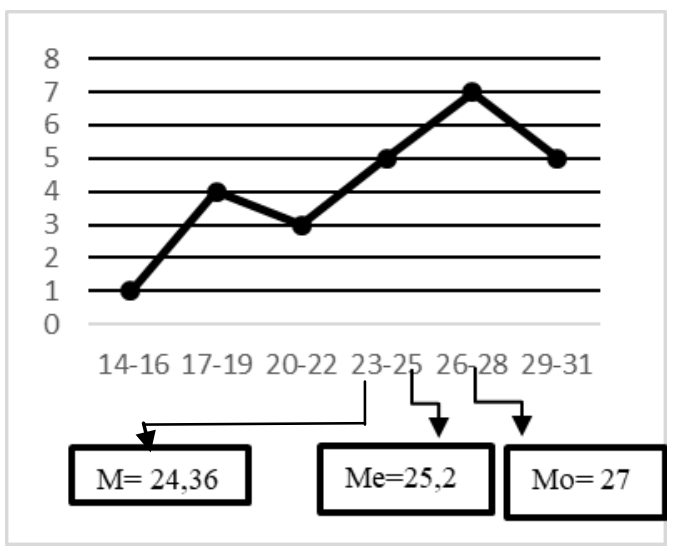

Gambar 1. Kurva Poligon Hasil Belajar PKn Kelompok Eksperimen

Berdasarkan kurva polygon diatas, diketahui modus lebih besar dari median dan median lebih besar dari mean (Mo>Md>M) yaitu 27>25,2>24,36, sehingga kurva diatas adalah kurva juling negatif. Artinya skor yang diperoleh adalah cenderung tinggi.

Data hasil belajar PKn pada kelompok kontrol dapat disajikan ke dalam bentuk kurva polygon seperti pada gambar 2 .

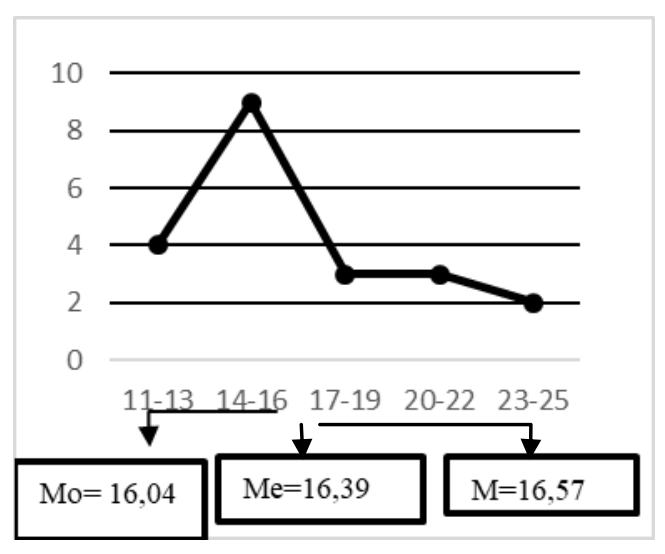

Gambar 2. Kurva Poligon Hasil Belajar PKn Kelompok Kontrol 
Berdasarkan kurva poligon di atas, dapat diketahui modus lebih kecil dari median dan median lebih kecil dari mean $\mathrm{Mo}<\mathrm{Md}<\mathrm{M}(16,04<16,39<16,57)$ sehingga kurva yang terbentuk adalah kurva juling positif. Artinya, skor yang diperoleh cenderung rendah.

Berdasarkan analisis data yang dilakukan dapat disajikan hasil uji normalitas sebaran data hasil belajar PKn kelompok eksperimen dan kelompok pada Tabel 1.

Tabel 1. Hasil Uji Normalitas Sebaran Data Skor Hasil Belajar PKn

\begin{tabular}{clccc}
\hline No. & Kelompok Data Hasil Belajar & $\mathrm{X}^{2}$ & $\begin{array}{c}\text { Nilai Kritis dengan Taraf } \\
\text { Signifikansi 5\% }\end{array}$ & Keterangan \\
\hline 1. & Kelompok Eksperimen & 6,051 & 7,815 & Normal \\
2. & Kelompok Kontrol & 4,78 & 5,59 & Normal \\
\hline
\end{tabular}

Berdasarkan hasil perhitungan menggunakan rumus Chi-Kuadrat, diperoleh bahwa data skor hasil belajar PKn kelompok eksperimen dan kelompok kontrol berdistribusi normal.

Pada penelitian ini, uji homogenitas dilakukan terhadap varians antarkelompok eksperimen dan kelompok kontrol. Uji yang digunakan adalah uji $\mathrm{F}$ dengan kriteria data homogen jika $F_{\text {hitung }}<F_{\text {tabel. }}$. Rekapitulasi hasil uji homogenitas varians antarkelompok eksperimen dan kelompok kontrol disajikan pada Tabel 2.

Tabel 2. Hasil Uji Homogenitas Sebaran Data Skor Hasil Belajar PKn

\begin{tabular}{lllcc}
\hline Sumber Data & Varians & $\mathrm{F}_{\text {hitung }}$ & $\mathrm{F}_{\text {tabel }}$ dengan Taraf Signifikansi 5\% & Status \\
\hline Kelompok Eksperimen & 20,91 & 1,31 & 2,12 & Homogen \\
Kelompok Kontrol & 15,96 & 1,31 & & \\
\hline
\end{tabular}

Berdasarkan Tabel 2 dapat diketahui bahwa varians data hasil bellajar PKn kelompok eksperimen dan kelompok kontrol homogen. Untuk pembuktian hipotesis yang diajukan dilakukan pengujian dengan menggunakan uji-t sampel independent (tidak berkolerasi) dengan rumus polled varians. Adapun hasil analisis uji-t disajikan pada Tabel 3.

Tabel 3. Rangkuman Hasil Perhitungan Uji-t.

\begin{tabular}{cccccccc}
\hline Data & Kelompok & $\mathrm{N}$ & Mean $(\bar{X})$ & $\mathrm{s}^{2}$ & $\mathrm{t}_{\text {hit }}$ & $\mathrm{T}_{\text {tab }}$ (t.s 5\%) & Kesimpulan \\
\hline Post- & Eksperimen & 25 & 24,36 & 20,91 & 6,092 & 2,000 & $\mathrm{t}_{\text {hitung }}>\mathrm{t}_{\text {tabel }}$ \\
test & Kontrol & 21 & 16,57 & 15,96 & & & $\mathrm{H}_{0}$ ditolak \\
\hline
\end{tabular}

Berdasarkan Tabel 3 dapat diketahui $t_{\text {hitung }}$ lebh besar dari $t_{\text {tabel }}\left(t_{\text {hitung }}>t_{\text {tabel }}\right)$, sehingga $H_{0}$ ditolak dan $\mathrm{H}_{1}$ diterima. Dengan demikian dapat diinterpretasikan bahwa terdapat perbedaan yang signifikan antara kelompok siswa yang belajar dengan menggunakan model pembelajaran VCT berbantuan media video dan kelompok yang dibelajarkan dengan pembelajaran konvensional pada siswa kelas V SD di Gugus III Kecamatan Seririt Tahun Pelajaran 2017/2018.

Berdasarkan penelitian yang dilakukan, terdapat perbedaan rata-rata hasil belajar PKn pada kelompok eksperimen dan kelompok kontrol. Secara deksriptif, hasil belajar PKn kelompok eksperimen lebih tinggi dibandingkan dengan kelompok kontrol. Perbedaan tersebut menunjukkan bahwa model pembelajaran VCT berbantuan media video berpengaruh terhadap hasil belajar PKn siswa kelas V. Perbedaan hasil belajar tersebut disebabkan oleh beberapa faktor sebagai berikut.

Pertama, pembelajaran dengan menggunakan model Value Clarification Technique dapat mengubah pembelajaran yang berspusat pada guru menjadi berpusat pada siswa. Dimana peran guru hanya sebagai fasilitator dan motivator. Peran guru sebagai fasilitator 
terlihat pada saat memberikan tanggung jawab kepada siswa untuk menemukan sendiri tentang nilai-nilai yang terkandung dalam dirinya. Sedangkan peran guru sebagai motivator tercermin pada proses pembelajaran guru selalu memberikan motivasi bagi siswa untuk dapat menemukan nilai yang terkandung dalam dirinya dan selanjutnya siswa dimotivasi untuk mengaplikasikan nilai yang dimilikinya. Sejalan dengan pendapat ini Fitriani (2016) menyatakan, peran guru sebagai fasilitator dan motivator yaitu selalu memberikan kesempatan kepada peserta didik untuk berpartisipasi, mengembangkan kemampuan serta keberanian dalam mengemukakan pendapat, dengan demikian akan tercipta proses pembelajaran yang interaktif dalam kegiatan belajar mengajar di kelas.

Kedua, model pembelajaran VCT memiliki beberapa tingkatan dalam pelaksanaanya diantaranya yaitu tingkat pertama dalam model VCT adalah tingkat kebebasan dalam memilih, tingkat kedua yaitu menghargai pilihannya dan tingkat ketiga yaitu berbuat (bertindak). Ketiga tahapan ini dapat menumbuhkembangkan kemampuan dan pemahaman siswa terhadap suatu nilai. Pada tahap pertama dalam proses pembelajaran adalah tingkat kebebasan dalam memilih. Kebebasan dalam memilih yang dimaksud adalah bebas dari segala bentuk tekanan. Tekanan yang dimaksud adalah tekanan yang berasal dari luar diri siswa, misalnya lingkungan. Siswa yang merasa memiliki kebebasan dalam memilih nilai kemudian dihadapkan pada berbagai alternatif nilai yang ada di sekitarnya. Berbagai alternatif nilai yang dihadapi siswa akan memicu siswa untuk berpikir dan menentukan nilai yang sesuai dengan dirinya sendiri dengan mempertimbangkan setiap konsekuensinya. Hal ini sesuai dengan pendapat Hernivora (2014) yang menyatakan, tujuan dari tingkat pertama dalam model VCT, yaitu siswa dapat menentukan nilai sesuai pertimbangan dan keyakinannya sendiri. Dalam proses pembelajaran hal ini terlihat dari keberanian siswa untuk mengungkapkan pendapatnya tentang materi yang sedang dipelajari.

Tingkatan kedua dalam model VCT, yaitu tingkat menghargai. Nilai yang dimiliki seseorang haruslah menimbulkan rasa senang dan bahagia sebagai bentuk keyakinannya pada nilai tersebut. Keyakinan tersebut juga berpengaruh pada keberanian orang tersebut untuk mengakui nilai-nilai yang dimilikinya di depan umum. Jika seseorang yakin dengan nilai yang dimilikinya maka dia akan dengan bangga mengakui hal itu di depan orang lain, dan begitu pula sebaliknya Hal ini sesuai dengan pendapat Hernivora (2014) yang menyatakan pada saat proses pembelajaran siswa yang sudah menemukan keyakinannya pada suatu nilai, dalam hal ini adalah pendapat, maka siswa tersebut akan dengan yakin menyampaikan pendapatnya di depan teman-temannya.

Tingkatan yang ketiga dalam model VCT adalah tingkat bertindak. Bertindak yang dimaksud adalah mampu menunjukkan nilai-nilai yang sudah dipelajarinya dalam bentuk sikap. Bertindak berdasarkan nilai yang diyakininya hendaknya dilakukan secara berulang-ulang agar menjadi kebiasaan hidup. Inilah tujuan tingkatan yang ketiga, yaitu siswa dapat menunjukkan nilai yang dimilikinya dalam bentuk sikap dan mengulanginya sebagai suatu kebiasaan hidup. Sikap yang diharapkan terbentuk dari proses pembelajaran dengan model VCT adalah sikapsikap yang baik. Hal ini sesuai dengan pendapat, Anggarini (2013) menyatakan bahwa, model VCT mampu menuntun serta membina sikap seseorang untuk berbuat serta bertingkah laku sesuai dengan nilai-nilai yang telah dipelajarinya. Itu berarti sikap siswa dapat dibina dengan penggunaan model pembelajaran yang mengacu pada pendidikan nilai.

Ketiga, penggunaan media pembelajaran video membantu siswa lebih memahami materi yang dipelajari. Penggunaan media video dapat menghidupkan suasana pembelajaran di kelas, sehingga siswa tidak bosan mengikuti pembelajaran. Selain hal tersebut, dengan media video siswa menjadi lebih termotivasi dalam belajar, sehingga siswa lebih mudah memahami materi yang dipelajari. Dengan demikian, dapat dikatakan bahwa media pembelajaran dapat meningkatkan keaktifan siswa dalam pembelajaran dan membantu siswa dalam menyerap materi pelajaran dengan lebih baik. Pendapat tersebut sesuai dengan hasi penelitian Alvionita (2013) yang menyatakan, media video dapat merangsang siswa untuk melakukan aktivitas yang relevan dalam pembelajaran. Hal ini terbukti dari aktivitas siswa dalam bertanya, menjawab petanyaan, mengajukan pendapat/ide dalam diskusi, dan mempresentasikan hasil 
diskusi yang dilakukan siswa pada kelas berkriteria tinggi. Peningkatan aktivitas tersebut dapat mempengaruhi peningkatan penguasaan materi siswa.

Berbeda halnya dengan kelas yang menggunakan pembelajaran konvensional. Pembelajaran yang seperti ini guru cenderung lebih aktif sebagai sumber informasi bagi siswa. Kepasifan siswa menjadikan komunikasi yang terjalin hanya komunikasi satu arah yaitu antara guru dengan siswa.

Perbedaan tersebut dapat memberikan dampak yang berbeda pula terhadap hasil belajar PKn antara pembelajaran yang menggunakan model pembelajaran Value Clarification Technique berbantuan media video dengan pembelajaran konvensional. Dengan demikian dapat disimpulkan bahwa model pembelajaran menggunakan model pembelajaran Value Clarification Technique berbantuan media video berpengaruh positif terhadap hasil belajar PKn siswa kelas V di SD N 3 Seririt, Kecamatan Seririt Tahun Pelajaran 2017/2018.

Temuan hasil penelitian ini sesuai dengan hasil temuan sebelumnya. Temuan hasil penelitian tersebut antara lain Nandari (2013) menyatakan bahwa model pembelajaran VCT bermuatan cerita berdilema moral memberikan pengaruh postif terhadap hasil belajar PKn. Hal ini dikarenakan model pembelajaran VCT melatih siswa aktif dalam mecari informasi dan mengemukakan pendapat serta membuat kesimpulan sendiri menurut nilai yang dianutnya. Sedangkaan cerita berdilema moral merupakan tuturan cerita yang mengembangkan daya piker moral kognitif dengan serangkaian moral berkenaan dengan karakter atau kelakuan apa yang seharusnya dilakukan manusia. Selanjutnya Putra (2014) menyatakan bahwa model pembelajaran VCT memberikan pengaruh postif terhadap hasil belajar PKn hal ini disebabkan oleh model pembelajaran VCT memberikan kesempatan kepada siswa untuk menyelidiki problema dalam kelompok kecil/kelas. Selain itu dengan menerapkan model VCT pembelajaran menjadi efektif serta siswa mampu terlibat aktif dalam pembelajaran

\section{Simpulan dan Saran}

Terdapat perbedaan yang signifikan hasil belajar PKn antara kelompok siswa yang dibelajarkan dengan model pembelajaran VCT bebrantuan media video dan kelompok siswa yang dibelajarkan dengan model pembelajaran konvensional pada siswa kelas V SD di Gugus III Kecamatan Seririt Tahun Pelajaran 2017/2018. Hasil pengujian menunjukan bahwa thitung $=6,092>$ ttabel $=2,000$ pada taraf signifikansi $5 \%$ berati $\mathrm{H} 0$ ditolak dan $\mathrm{H} 1$ diterima.

Model pembelajaran Value Clarification Technique berbantuan media video berkontribusi dalam meningkatkan hasil belajar PKn siswa yang mana paradigma pembelajaran berubah dari yang berpusat pada guru menjadi berpusat pada siswa peran guru hanya sebagai fasilitator dan motivator. Dalam pembelajaran siswa dilibatkan secara langsung untuk menggali pengetahuan dan pemahamannya, sehingga apa yang telah dipelajari menjadi lebih bermakna dan bertahan lama dalam ingata siswa.

Saran yang dapat disampaikan berdasarkan penelitian yang telah dilakukan adalah sebagai berikut. 1) Guru di sekolah dasar hendaknya lebih berinovasi dalam pembelajaran salah satunya dengan model pembelajaran Value Clarification Technique untuk dapat meningkatkan motivasi dan keaktifan siswa dalam pembelajaran sehingga hasil belajar meningkat, sebab telah terbukti pada penelitian ini bahwa terdapat perbedaan hasil belajar yang signifikan antara kelompok siswa yang belajar dengan model pembelajaran Value Clarification Technique dan kelompok siswa yang dibelajarkan dengan pembelajaran konvensional. 2) Kepada kepala sekolah hendaknya mengikutkan guru-guru dalam pelatihan mengenai pembelajaran inovatif dan mengupayakan untuk menambah media pembelajaran yang relevan dengan pembelajaran di sekolah. 3) Kepada peneliti lain yang berminat untuk mengadakan penelitian lebih lanjut tentang model pembelajaran Value Clarification Technique dalam bidang pendidikan khususnya pada mata pelajaran PKn agar memperhatikan kendalakendala yang dialami dalam penelitian ini sebagai bahan petimbangan untuk perbaikan dan penyempurnaan penelitian yang akan dilaksanakan. 


\section{Daftar Rujukan}

Adisusilo, Sutarjo. 2014. Pembelajaran Nilai-Karakter Konstrutuktivisme dan VCT Sebagai Inovasi Pendekatan Pembelajaran Afektif. Jakarta: Rajawali Pers.

Alvionita, Vivi. 2013. "Pengaruh Penerapan Media Video Terhadap Aktivitas dan Penguasaan Materi Pokok Sistem Pernapasan”. Jurnal Bioterdidik, Volume 1, No 7 (hal 8).

Anggarini, Dewi. 2013. "Pengaruh Model Pembelajaran Value Clarification Technique Berbantuan Media Gambar Terhadap Nilai Karakter Siswa Kelas V SD Gugus VI Tajun". Jurnal Mimbar PGSD. Vol. 2 No 1.

Hernivora, Paramita. 2014. "Pengaruh Model Pembelajaran VCT Berbantuan Cerita Mahabharata Terhadap Nilai Karakter Siswa Kelas 5 Pada Pelajaran PKn Semester I Gugus 5 Mandara Giri Tamblang Kecamatan Kubutambahan Tahun Pelajaran 2013/2014". Jurnal Mimbar Pendidikan Guru Sekolah Dasar Universitas Pendidikan Ganesha. Volume 1.

Fitriani, Vetty, dkk. 2016. "Penerapan Model VCT (Value Clarification Technique) Dengan Menggunakan Media Cerita Daerah Dalam Pembelajaran Pendidikan Kewarganegaraan Untuk Meningkatkan Karakter Peserta Didik". Jurnal Pendidikan IImu Sosial. Vol. 25 No. 1.

Nandari, Tri. 2013. "Pengaruh Model Pembelajaran VCT Bermuatan Cerita Berdilema Moral Terhadap Hasil Belajar Pendidikan Kewarganegaraan Siswa Kelas IV SD Negeri 1 Kamasan". Jurnal Mimbar Pendidikan Guru Sekolah Dasar Vol. 2 No.1.

Putra, I Dewa Made Arta. 2014. "Pengaruh Model Pembelajaran Value Clarification Technique (VCT) Terhadap Hasil Belajar PKn Siswa Kelas V". Jurnal Mimbar Pendidikan Guru Sekolah Dasar.Volume: 2 No.1.

Susanto, Ahmad. 2013. Teori Belajar dan Pembelajaran di Sekolah Dasar. Jakarta: Kencana Prenada Media Group.

Suwatra, Ign I Wayan, dkk. 2015. Belajar dan Pembelajaran Sekolah Dasar. Singaraja: Universitas Pendidikan Ganesha.

Syaifuddin, Mohammad. 2007. Manajemen Berbasis Sekolah. Jakarta: Direktorat Jenederal Pendidikan Tinggi Departemen Pendidikan Nasional.

Widiantari, Ni Nyoman. 2013 "Pengaruh Model Pembelajaran Scramble Berbantuan Media Video Terhadap Hasil Belajar IPA Siswa Kelas IV SD Di Gugus V Kecamatan Buleleng". Jurnal Mimbar Pendidikan Guru Sekolah Dasar. Volume: 2 No.1.

Yuliasri, Sri. 2013. "Pengaruh Model Pembelajaran VCT Berbantuan Media Power Point Terhadap Hasil Belajar PKn Siswa Kelas V SD Gugus V Kecamatan Buleleng”. Jurnal Mimbar Pendidikan Guru Sekolah Dasar. Volume1. 